International Journal of Management and Sustainability

2014 Vol.3, No.12, pp.673-683

$\operatorname{ISSN}(e): 2306-0662$

$\operatorname{ISSN}(p): 2306-9856$

DOI: 10.18488/journal.11/2014.3.12/11.12.673.683

(C) 2014 Conscientia Beam. All Rights Reserved.

(D) ${ }_{\text {crossMark }}$

\title{
IMPACT OF FAMILY OWNERSHIP ON MARKET VALUE OF A FIRM: A COMPARATIVE ANALYSIS OF FAMILY AND NON-FAMILY COMPANIES LISTED AT KARACHI STOCK EXCHANGE (PAKISTAN)
}

\author{
Safdar Husain Tahir ${ }^{1 *}$--- Hazoor Muhammad Sabir ${ }^{2}$ \\ 'Assistant Professor Banking \& Finance, Government College University Faisalabad, Pakistan \\ ${ }^{2}$ Professor Management $\mathbb{\Xi}^{\circ}$ Admin Sciences, Government College University Faisalabad, Pakistan
}

\begin{abstract}
The current study attempts to investigate the impact of family ownership structure on value of firms listed at the Karachi Stock Exchange (KSE) of Pakistan. For the distinction of FOB from Non-FOB, two threshold points (25\% \& 50\%) of ownership structure are used. A sample of 280 listed firms at KSE is collected ranging for the period 2002-13. Generalized Method of Moments (GMM) is applied on panel data to estimate the coefficients of variables. The empirical results indicate that the family firms outperform the non-family ones. The better performance of young generation of family firms over succeeding generation is also revealed but professional chief executive officer (CEO) over family member is preferred. Furthermore, this study discovers inflection points i.e. (62\% \& 57\%) for family and non-family firms under quadratic specification respectively.
\end{abstract}

Keywords: Family business, Firm's value, GMM, Karachi stock exchange (KSE), Ownership concentration, Panel data.

JEL Classification: Moo, Zoo.

Received: 19 January 2015/ Revised: 10 February 2015/ Accepted: 4 March 2015/ Published: 16 March 2015

\section{Contribution of Study}

This study is one of very few studies which have investigated the impact of family ownership on firm's value in Pakistan. The prolific nature of family businesses in emerging economies makes the subject matter hot in recent business studies. As a comparative analysis, this study not only provides guidelines or instructions to family managers but also to the authorities of non-family businesses. In this way, this study is a lighthouse for both organizational types existing in business environment around the globe. 


\section{INTRODUCTION}

In the current study, ownership control in terms of family and non-family business and its impact on firm's value is investigated in the context of Pakistan. The study documents the arguments that motivate to dig out critical issues regarding corporate performance as well as governance perspectives. It explicates the fundamental arguments that encourage the current investigation, the ownership concentration and its crucial role in the developed and developing economies in all over the world. A large number of business organizations are owned by families as FOBs have become important model in the world particularly in emerging economies. About 80-90 percent business of United State of America (U.S.A) consists of FOBs. In Europe, 80 percent business organizations are operating in the form of FOBs. The ratios of FOBs range from 70- 90 percent in Middle East and 60-70 percent for Australia. Asia is also dominated by FOBs as most of the Chinese and Japanese companies are considered to be family business. Mostly these companies are based in associated countries. Similarly, in India FOBs account for approximately 85 percent of all Indian business firms (Deloitte, 2013). The picture for FOBs in Pakistan is not different from India as it is dominant in the business community of Pakistan (Ghani and Ashraf, 2005).

Theoretically and empirically, ambiguous and complex relationships exist between ownership concentration and firm value. The presence of large number of blockholders in ownership structure indicates strict monitoring of management over decision making process because blockholders having large stake tend to safeguard their assets proactively. Blockholders may keen to take rapid actions against managers on poor performance and bad governance such as replacement of chief executive officer (CEO) and the election of board.

Therefore, ownership concentration can be used as a tool of governance over managerial activities that help to control managerial opportunism.

Contrary to ownership concentration, diffused ownership less likely takes quick actions against the managers over poor performance as they are not fully motivated to discipline the behavior of management. One the one hand, ownership concentration is generally assume to provide incentive to manage and control the business organizations. On the other hand, dispersed ownership seems to provide better cooperative environment and give operational benefits to every business. As an example, in the context of risk management, dispersed ownership offers diversification to investors while concentrated ownership executes additional risk premium which ultimate create under investment problem because of instinctive risk aversion of large shareholders (Demsetz and Lehn, 1985). Yet more critical issue, the conflicts among large and small shareholders due to ownership concentration may emerge out in the form of agency problem. 


\section{REVIEW OF LITERATURE}

Shahab-U-Din et al. (2013) find a positive relation between ownership variable and firm's performance using a sample of 29 non-financial firms from KSE-100 index. They take ownership variable is the percentage of ownership shares hold by family members. Nazir et al. (2013) find significant positive effect of ownership concentration on corporate performance using panel data methodology taking 125 listed companies from Karachi Stock exchange Pakistan. They prove that ownership concentration can efficiently be used as a corporate strategy and plays momentous role to enhance the performance of firms in Pakistani environment. Phung and Hoang (2013) examine the effect of ownership structure and firm performance and reveal that an inverted $\mathrm{U}_{-}$ shaped relation between state ownership and performance while foreign ownership upsurge the profitability. Isik and Saykan (2013) empirically investigate the association between largest shareholders and firm's performance; and show that significant positive relation between them.

The recent research studies, comparative analysis on family ownership concentration with other forms of organizational ownership, highlights the importance of general block holder effect on firm's performance. Nguyen and Nielsen (2013) analyze the impact of ownership and control on corporate value by using reaction of stock in connection with death of individual blockholders. They indicate the reaction range from -5 to 4 percent for insider blockholder and -2 percent for outsider blockholders. Konijn et al. (2011) conclude negative effect of blockholders on performance by using widespread phenomenon of multiple blockholders of U.S companies. They suggest dispersed blockholders as compared to concentrated blockholders as the later show more negative results relatively. La Porta et al. (1999), Bebchuk et al. (2009) and Gomes (2000) in their works show that in the countries where institutional and legal frameworks do not insurance reasonable protection for external investors, ownership concentration can alleviate the conflicts among shareholders. Furthermore, in such kind of environment, only reasonable equilibrium among the shareholders can save and protect the minority shareholders (Gomes, 2000).

Salloum et al. (2013) find that the involvement of family member in management has positive impact on financial performance in Lebanon. Additionally, they show insignificant impact of entrenchment as well as asymmetric altruism on financial performance. Noor Afza (2011) examines the relation between $\mathrm{CEO}$-founder and CEO-successor with respect to performance of firm. She concludes that the firms operating under CEO-successor create more value than their counterparts in Malaysian family owned companies using Tobin $Q$ and earning per share (EPS) as performance variables. Also, she finds young owners are more aggressive to boost up the value of business as compared to old owners of family business in Malaysia but age does positive influence on firm's performance. Fitriya and Stuart (2012) confirm the non-linear relationship between ownership structure and corporate performance by apply Generalized Linear Model (GLM) in the firms listed on New Zealand Stock Exchange. 


\section{METHODOLOGY}

The main sources of our information are the annual reports, financial statements. Basic balance sheet analyses issued by State Bank of Pakistan (SBP) form the period spanning of 2002 to 2013 are also used. The sample of study consists of 280 non-financial companies listed at Karachi Stock Exchange (KSE). Panel data methodology and Generalized Method of Moments (GMM) help to control the unobservable problems termed as heterogeneity and endogeneity. Finally, the potential misspecification of the models is checked by two ways called Hansen Jstatistic and $\mathrm{m}_{2}$ statistic. The Wald tests $\left(\mathrm{w}_{1}\right.$ and $\left.\mathrm{w}_{2}\right)$ are applied to test the joint significance of coefficients and time dummy variables respectively.

\subsection{Definition of Family Owned Business (FOB)}

A firm is said to be family owned business (FOBs), if family directors have managerial ownership or voting rights $25 \%$ and $50 \%$ in the firm. $25 \%$ cut off point is proposed in the official definition of GEEF* by its French name. It is also in line with the definition adopted by Board of Family Business Network in April 7, 2008. 50\% cut off point is used because ownership at this level confers the unequivocal control rights (Doidge et al., 2005). Also, particularly in Pakistan, owners of family companies hold more than 50\% shareholdings (Attiya and Javaid Iqbal, 2010)

\subsection{Hypotheses}

$H_{l}$ Ownership Concentration of FOBs impact higher on Firm's Value than NFOBs.

$H_{\text {: }}$ Ownership Concentration of FOBs impact higher on Firm's Value than NFOB holds after controlling for the block holder effect.

$H_{s:}$ The young FOBs do perform better than the old ones.

$H_{i}$ : There is positive impact of ownership concentration on firm's Value in those FOBs where founder or his descendant serves as chief executive officer (CEO).

$H_{5:}$ There is nonlinear relationship between ownership concentration and firm's Value in FOBs

\subsection{Models Specification}

$\mathrm{FV}_{\mathrm{it}}=\alpha_{0}+(\beta+\gamma \mathrm{FOB}) \mathrm{OC}_{\mathrm{it}}+\mu \mathrm{K}_{\mathrm{it}}+\epsilon_{\mathrm{it}}$
$\mathrm{FV}_{\mathrm{it}}=\alpha_{0}+(\beta+\gamma \mathrm{FOB}+\delta \mathrm{BH}) \mathrm{OC}_{\mathrm{it}}+\mu \mathrm{K}_{\mathrm{it}}+\epsilon_{\mathrm{it}}-$
$\mathrm{FV}_{\mathrm{it}}=\alpha_{0}+\left(\beta+\Phi_{1} \mathrm{FGFOB}+\Phi_{2} \mathrm{SGFOB}\right) \mathrm{OC}_{\mathrm{it}}+{ }_{\mu} \mathrm{K}_{\mathrm{it}}+\epsilon_{\mathrm{it}}$
$\mathrm{FV}_{\mathrm{it}}=\alpha_{\mathrm{O}}+\left(\beta+\Phi_{1} \mathrm{FCEO} \mathrm{FOB}+\Phi_{2} \mathrm{NFCEOFOB}\right) \mathrm{OC}_{\mathrm{it}}+{ }_{\mu} \mathrm{K}_{\mathrm{it}}+\epsilon_{\mathrm{it}}-$
$\mathrm{FV}_{\mathrm{it}}=\alpha_{0}+(\beta+\gamma \mathrm{FOB}) \mathrm{OC}_{\mathrm{it}}+\left(\beta_{1}+\gamma_{1} \mathrm{FOB}\right) \mathrm{OC}_{\mathrm{it}}+{ }_{\mu} \mathrm{K}_{\mathrm{it}}+\epsilon_{\mathrm{it}}$

Where

$\mathrm{FV}_{\text {it }}=$ Firm's Value

$\mathrm{OC}_{\mathrm{it}}=$ Ownership Concentration

$K_{\mathrm{it}}=$ Firm's set characteristics such as (Size, Debt ratio, Cash flow, Average Receivables and Age) 
FOB $=$ Dummy variable equal to 1 for Family firms and o for non-family firms.

$\mathrm{BH}=$ Dummy variable equal to 1 for presence of insider blockholder and zero otherwise

FGFOB $=$ Dummy variable equal to 1 for first generation family firms and 0 otherwise

$\mathrm{SGFOB}=$ Dummy variable equal to 1 for second generation family firms and 0 otherwise

FCEOFOB $=$ Dummy variable equal to 1 for family member serves as CEO in family firms and $O$ otherwise

$\mathrm{NFCEOFOB}=$ Dummy variable equal to 1 for family member serves as CEO in family firms and 0 otherwise

$€_{i \mathrm{t}}=$ Error term

\section{EMPIRICAL RESULTS}

\subsection{Summary Statistics}

This table-2 shows summary statistics of the full sample used in the study. It contains means, medians, standard deviations, minimums and maximums of the variables applied in the analyses. The correlation matrix of the variables can be seen in the table panel B. The sample contains 3360 observations of 280 companies from non-financial sector listed at Karachi Stock Exchange (KSE) Pakistan. The FVit and IAFVit are termed as firm's value and industry adjusted firm's value respectively. The ownership concentration (OCit) is the percentage of first three largest shareholders of the companies. SIZE $E_{i t}$ is the natural $\log$ of total assets, DEBT it $_{\text {it }}$ denotes debt to total asset ratio, and CFit is the cashflow of corresponding year. Similarly $\mathrm{AGE}_{i t}$ is the natural $\log$ of firm age since incorporated.

Table-1. Panel-(A). Summary Statistics for the full sample

\begin{tabular}{|c|c|c|c|c|c|}
\hline Variables & Mean & Median & Standard deviation & Minimum & Maximum \\
\hline $\mathrm{FV}_{\text {it }}$ & 0.865 & 0.635 & 0.872 & 0.120 & 9.760 \\
\hline IAFV $_{\text {it }}$ & 0.235 & -0.140 & 0.824 & -0.990 & 8.060 \\
\hline OCit & 26.45 & 24.420 & 0.209 & 0.050 & 98.00 \\
\hline $\mathrm{SIZE}_{\text {it }}$ & 9.159 & 7.927 & 10.120 & 1.325 & 12.478 \\
\hline DEBT $_{\text {it }}$ & 0.743 & 0.708 & 0.361 & 0.110 & 0.990 \\
\hline $\mathrm{CF}_{\text {it }}$ & 0.060 & 0.053 & 0.191 & -1.213 & 0.445 \\
\hline $\mathrm{AR}_{\text {it }}$ & 2.468 & 2.288 & 1.274 & 1.000 & 3.680 \\
\hline $\mathrm{AGE}_{\mathrm{it}}$ & 3.210 & 3.121 & 3.510 & 2.639 & 4.189 \\
\hline
\end{tabular}

Panel-(B). Summary Correlation Matrix

\begin{tabular}{|c|c|c|c|c|c|c|c|c|}
\hline & $\overline{F V_{\text {it }}}$ & IAFV $_{\text {it }}$ & OCit & SIZE $_{\text {it }}$ & DEBT $_{\text {it }}$ & $\overline{\mathbf{C F}_{\text {it }}}$ & SALES $_{\text {it }}$ & $\overline{\mathrm{AGE}_{\text {it }}}$ \\
\hline $\mathrm{FV}_{\text {it }}$ & 1.000 & & & & & & & \\
\hline $\mathrm{IAFV}_{\text {it }}$ & 0.987 & 1.000 & & & & & & \\
\hline OCit & -0.032 & -0.001 & 1.000 & & & & & \\
\hline $\mathrm{SIZE}_{\text {it }}$ & -0.043 & -0.018 & -0.12 & 1.000 & & & & \\
\hline DEBT $_{\text {it }}$ & -0.386 & -0.361 & 0.101 & 0.067 & 1.000 & & & \\
\hline $\mathrm{CF}_{\text {it }}$ & 0.278 & 0.221 & 0.009 & 0.076 & -0.216 & 1.000 & & \\
\hline SALES $_{\text {it }}$ & 0.843 & 0.768 & 0.018 & 0.553 & 0.034 & 0.845 & 1.000 & \\
\hline $\mathrm{AGE}_{\text {it }}$ & -0.271 & -0.189 & 0.045 & 0.278 & 0.080 & -0.009 & -0.002 & 1.000 \\
\hline
\end{tabular}


Data mentioned in the panel A and B of Table-2 provides the summary statistics and correlation of the variables used in the analysis of the study. It is observed that the mean value of ownership concentration in the full sample is $26 \%$ indicates the existing of high proportion of family business in the country. The mean value of size is 9.159 , indicating large companies in full data sample. The average value of debt is $74.30 \%$ with ranging from $11 \%$ to $99 \%$. Two issues are prominent in the data panel (A). First, there is high positive correlation in between both performance variables. Second, there is negative correlation between ownership concentration and performance variables.

\subsection{Descriptive Analysis}

As indicated in the Table-2, the category falls in family owned businesses (FOBs) significantly outperform the rest of the companies. Moreover, this better performance of FOBs with respect to NFOBs is more prominent in case of the Industry Adjusted Firm's Value (IAFV it) is used as a measure of performance variable. Further, this finding supports the argument of industry effect in the estimation procedure of the empirical models.

This table- 2 shows the preliminary analysis of means tests between family owned businesses (FOBs) and non-family owned businesses (NFOB) in their ownership and financial characteristics. The sample contains 3360 observations of 280 companies from non-financial sector listed at Karachi Stock Exchange (KSE) Pakistan. The ownership concentration $\left(\mathrm{OC}_{\mathrm{it}}\right)$ is the percentage of first three largest shareholders of the companies. The $\mathrm{FV}_{\text {it and }} \mathrm{IAFV}_{\mathrm{it}}$ are termed as firm's value and industry adjusted firm's value respectively. SIZE $\mathrm{E}_{\mathrm{it}}$ is the natural $\log$ of total assets, $\mathrm{DEBT}_{\mathrm{it}}$ denotes debt to total asset ratio, and $\mathrm{CF}_{\text {it }}$ is the cashflow of corresponding year. Similarly $\mathrm{AGE}_{\mathrm{it}}$ is the natural $\log$ of firm age since incorporated. The t-statistic tests are applied to measure the means difference under the null hypothesis. $\mathrm{H}_{0}$ : Mean $\mathrm{FOB}-\mathrm{Mean} \mathrm{NFOB}=0$. The $* * *$, **, and *indicate significance at the $10 \%, 5 \%$ and $1 \%$ level respectively.

The table-5 consists on the subsamples of performance variables for FOBs and NFOBs companies. The sample contains 3360 observations of 280 companies of non-financial sector listed at Karachi Stock Exchange (KSE) Pakistan for which data available for consecutive twelve years from 2002 to 2013. Two threshold criterions (25\% and 50\%) for differentiation of FOB and $\mathrm{NFOB}$ are used in the classification procedure.. All the variables that are applied to classify subsample of FOB as defined in Appendix 1(A), 1(B) and 1(C). FV it and IAFV $_{\text {it }}$ indicate firm's value and industry adjusted firm's value respectively.

FOBs further are classified into two subsamples i.e. FOBs where family member works as $\mathrm{CEO}$ or no family member as CEO. Similarly first generation FOBs and succeeding generation FOBs are used as subsample of FOBs. 30 year age cut off point is used to distinguish first generation from succeeding generation. The $*^{* * *}, * *$, and $*$ indicate significance at the $10 \%, 5 \%$ and $1 \%$ level respectively. 
Table-2. Descriptive analysis performance variables and firm's characteristics

\begin{tabular}{|c|c|c|c|c|c|}
\hline & & All Companies & FOB & NFOB & t-statistic \\
\hline \multirow{9}{*}{ 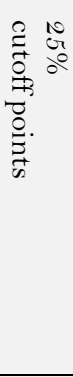 } & No of Obsv. & 3360 & 2628 & 732 & \\
\hline & $\mathrm{FV}_{\text {it }}$ & 0.865 & 0.878 & 0.818 & 0.04 \\
\hline & IAFV $_{\text {it }}$ & 0.235 & 0.254 & 0.167 & $2.28^{* *}$ \\
\hline & $\mathrm{OC}_{\mathrm{it}}$ & 26.450 & 28.200 & 20.160 & $14.67^{*}$ \\
\hline & $\mathrm{SIZE}_{\text {it }}$ & 9.159 & 8.689 & 10.846 & $-9.45^{*}$ \\
\hline & DEBT $_{\text {it }}$ & 0.743 & 0.768 & 0.653 & $3.94^{*}$ \\
\hline & $\mathrm{CF}_{\text {it }}$ & 0.060 & 0.060 & 0.060 & $-1.51^{* * * *}$ \\
\hline & $\mathrm{AR}_{\text {it }}$ & 2.468 & 2.498 & 2.360 & -0.08 \\
\hline & $\mathrm{AGE}_{\mathrm{it}}$ & 3.98 & 3.44 & 4.48 & 0.38 \\
\hline \multirow{9}{*}{ 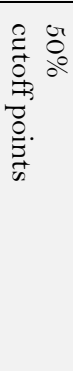 } & No of Obsv. & 3360 & 2004 & 1356 & \\
\hline & $\mathrm{FV}_{\text {it }}$ & 0.865 & 0.901 & 0.811 & $3.52^{*}$ \\
\hline & $\mathrm{IAFV}_{\text {it }}$ & 0.235 & 0.284 & 0.163 & $4.67^{*}$ \\
\hline & $\mathrm{OC}_{\mathrm{it}}$ & 26.450 & 33.385 & 16.201 & $24.67^{*}$ \\
\hline & $\mathrm{SIZE}_{\text {it }}$ & 9.159 & 8.512 & 10.115 & $-9.45^{*}$ \\
\hline & DEBT $_{\text {it }}$ & 0.743 & 0.793 & 0.669 & $3.24^{*}$ \\
\hline & $\mathrm{CF}_{\text {it }}$ & 0.060 & 0.060 & 0.060 & $-1.51^{* * * *}$ \\
\hline & $\mathrm{AR}_{\text {it }}$ & 2.468 & 2.504 & 2.414 & -0.09 \\
\hline & $\mathrm{AGE}_{\text {it }}$ & 3.98 & 3.99 & 3.965 & 0.38 \\
\hline
\end{tabular}

Table-3. Subsamples of FOB performance difference variables

\begin{tabular}{|c|c|c|c|c|c|c|}
\hline $\begin{array}{l}\text { FOB/ } \\
\text { NFOB }\end{array}$ & & $\begin{array}{l}\text { Family } \\
\text { Firms }\end{array}$ & $\begin{array}{l}\text { Family } \\
\text { member } \\
\text { CEO }\end{array}$ & $\begin{array}{l}\text { No-Family } \\
\text { member CEO }\end{array}$ & $\begin{array}{l}\text { First Generation } \\
\text { Family firm }\end{array}$ & $\begin{array}{l}\text { Succeeding Generation } \\
\text { Family firm }\end{array}$ \\
\hline \multirow{3}{*}{ 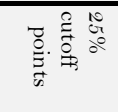 } & No. of Obs. & 2628 & 2220 & 408 & 648 & 1980 \\
\hline & $\mathrm{FV}_{\text {it }}$ & 0.878 & 0.881 & 0.862 & 0.891 & 0.874 \\
\hline & $\mathrm{IAFV}_{\text {it }}$ & 0.254 & 0.259 & 0.227 & 0.267 & 0.249 \\
\hline \multirow{3}{*}{ 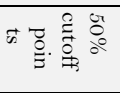 } & No. of Obs. & 2004 & 1704 & 300 & 600 & 1404 \\
\hline & $\mathrm{FV}_{\text {it }}$ & 0.910 & 0.914 & 0.887 & 0.948 & 0.894 \\
\hline & IAFV $_{\text {it }}$ & 0.284 & 0.289 & 0.256 & 0.367 & 0.197 \\
\hline
\end{tabular}

Table-3 shows the result of multivariate analyses other than the performance variables. Again, we use two cut off points according to definition of family owned business (FOB) and nonfamily owned business (NFOB). The results regarding means tests of different levels of ownership concentration remain unchanged. There are some interesting findings in the above shown Table3. First, there is higher level of ownership concentration in family owned business (FOB) as it is expected. Second, overall family firms have smaller size as compared to non-family ones but results are diametrically opposite in respect the debt levels are used by the business. Third, there slightly large cashflow in NFOBs as compared to FOBs but the results are not statistically significant. Fourth, there is no significant difference in term of age of family owned business (FOB) and non-family owned business (NFOB).

\subsection{Regression Results}

The results drawn by estimating the model (1) as shown in Table-2, indicate the positive impact of ownership concentration on firm's value. This impact for FOBs $\left(\beta^{\wedge}+\gamma^{\wedge}=0.59+1.12=\right.$ $1.71)$ and for NFOBs is $\left(\beta^{\wedge}=0.59\right)$ is statistically significant as indicated by value $t_{1}=9.43$. It 
means the stronger positive impact of ownership concentration on value in family companies than in non-family ones. Our finding is consistent with first hypothesis-1 i.e. the ownership Concentration of FOBs impact higher on Firm's Value than NFOBs. It is also corroborated with the argument that FOBs effectively monitor the operational and managerial activities. Consequently, they able to resolve the agency conflict between owner-managers relationship. The result is in line with the studies such like (Anderson and Reeb, 2003; Aguiló and Aguiló, 2012). The values shown in the table- 2 indicate that the influence of family control still prominent even after controlling the impact of general blockholder but the impact is non-significant.

As it is indicated, the impact of first generation family owned business (FOB) on value is $\beta^{\wedge}$ $+\Phi_{1} \wedge=0.69+1.82=2.51$, statistical significant and coefficient is more than the impact of succeeding generation $\left(\beta^{\wedge}+\Phi_{2}=0.69+0.81=1.50\right)$. These results support our hypothesis-3 that the young generation family owned business outperforms the succeeding generation family owned business.

Table-6. Ownership Concentration and Firm's value (25\% cut off point)

\begin{tabular}{|c|c|c|c|c|c|c|c|c|c|c|c|}
\hline \multirow{2}{*}{$\frac{\text { Variables }}{\text { Variables }}$} & \multirow[t]{2}{*}{ Co } & \multicolumn{2}{|c|}{ Model (1) } & \multicolumn{2}{|c|}{ Model (2) } & \multicolumn{2}{|c|}{ Model (3) } & \multicolumn{2}{|c|}{ Model (4) } & \multicolumn{2}{|c|}{ Model (5) } \\
\hline & & $\mathrm{CV}$ & $\mathrm{SE}$ & $\mathrm{CV}$ & $\mathrm{SE}$ & $\mathrm{CV}$ & $\mathrm{SE}$ & $\mathrm{CV}$ & $\mathrm{SE}$ & $\mathrm{CV}$ & $\mathrm{SE}$ \\
\hline constant & $\alpha_{0}$ & 0.19 & 0.28 & 0.11 & 0.23 & -0.09 & 0.24 & 0.26 & 0.21 & -0.08 & 0.26 \\
\hline OCit & $\beta$ & $0.59^{*}$ & 0.14 & $1.25^{*}$ & 0.38 & $0.69^{*}$ & 0.69 & $1.61 * *$ & 0.43 & $1.59^{*}$ & 0.28 \\
\hline $\mathrm{FOBOC}_{\mathrm{it}}$ & $\gamma$ & $1.12^{* * *}$ & 0.30 & 1.77 & 0.34 & & & & & 1.52 & 0.10 \\
\hline $\mathrm{BHOC}_{\text {it }}$ & $\delta$ & & & -0.53 & 0.32 & & & & & & \\
\hline FGFOBOC $_{\text {it }}$ & $\Phi_{1}$ & & & & & $1.82^{*}$ & 0.31 & & & & \\
\hline SGFOBOC $_{\text {it }}$ & $\Phi_{2}$ & & & & & $0.81^{*}$ & 0.18 & & & & \\
\hline FCEOFOBOC $_{\text {it }}$ & $\Phi_{3}$ & & & & & & & 1.12 & 0.28 & & \\
\hline $\mathrm{NFCEOFOBOC}_{\mathrm{it}}$ & $\Phi_{4}$ & & & & & & & 2.24 & 0.28 & & \\
\hline $\mathrm{OC}_{\mathrm{it}^{2}}{ }^{2}$ & $\beta_{1}$ & & & & & & & & & $-1.29 *$ & 0.30 \\
\hline FOBOC $_{\text {it }}{ }^{2}$ & $\gamma_{1}$ & & & & & & & & & $-1.42 *$ & 0.54 \\
\hline SIZE $_{\text {it }}$ & $\mu_{1}$ & 0.02 & 0.04 & $0.05^{*}$ & 0.03 & 0.08 & 0.07 & $0.03^{* * *}$ & 0.01 & $0.04 * *$ & 0.02 \\
\hline $\mathrm{DEBT}_{\text {it }}$ & $\mu_{2}$ & $-1.26^{*}$ & 0.12 & $\begin{array}{l}-1 . \\
43^{*}\end{array}$ & 0.15 & $\begin{array}{l}- \\
1.32 *\end{array}$ & 0.11 & $-1.38^{*}$ & 0.13 & $-1.67 *$ & 0.12 \\
\hline $\mathrm{CF}_{\text {it }}$ & $\mu_{3}$ & $1.71 *$ & 0.11 & $1.49^{*}$ & 0.12 & $1.70^{*}$ & 0.14 & $0.96^{*}$ & 0.09 & $0.77^{*}$ & 0.18 \\
\hline $\mathrm{AR}_{\text {it }}$ & $\mu_{4}$ & -1.09 & 0.08 & $\begin{array}{l}- \\
1.02 *\end{array}$ & 0.11 & -1.09 & 0.12 & -1.14 & 0.08 & -1.08 & 0.15 \\
\hline $\mathrm{AGE}_{\mathrm{it}}$ & $\mu_{5}$ & $-0.09^{*}$ & 0.01 & $\begin{array}{l}- \\
0.13^{*}\end{array}$ & 0.01 & $\begin{array}{l}-07 * \\
0.07\end{array}$ & 0.02 & $-0.08^{*}$ & 0.04 & $0.06^{* *}$ & 0.01 \\
\hline T-statistics & $\mathrm{t}_{1}$ & \multicolumn{2}{|l|}{9.43} & & & & & & & & \\
\hline T-statistics & $\mathrm{t}_{2}$ & & & \multicolumn{2}{|l|}{0.18} & & & & & & \\
\hline T-statistics & $\mathrm{t}_{3}$ & & & \multicolumn{2}{|l|}{0.78} & & & & & & \\
\hline T-statistics & $\mathrm{t}_{4}$ & & & & & \multicolumn{2}{|l|}{4.98} & & & & \\
\hline T-statistics & $\mathrm{t}_{5}$ & & & & & \multicolumn{2}{|l|}{8.47} & & & & \\
\hline T-statistics & $\mathrm{t}_{6}$ & & & & & & & \multicolumn{2}{|l|}{-1.09} & & \\
\hline T-statistics & $\mathrm{t}_{7}$ & & & & & & & \multicolumn{2}{|l|}{-1.03} & & \\
\hline T-statistics & $t_{8}$ & & & & & & & & & \multicolumn{2}{|l|}{-7.09} \\
\hline T-statistics & $t_{9}$ & & & & & & & & & -5.03 & \\
\hline Wald Test-1 & $\mathrm{w}_{1}$ & \multicolumn{2}{|c|}{$44.67(8)$} & \multicolumn{2}{|c|}{$67.74(8)$} & \multicolumn{2}{|c|}{$63.82(9)$} & \multicolumn{2}{|l|}{$53.57(9)$} & \multicolumn{2}{|l|}{$47.89(9)$} \\
\hline Wald Test-2 & $\mathrm{W}_{2}$ & \multicolumn{2}{|c|}{$61.01(5)$} & \multicolumn{2}{|c|}{$77.09(5)$} & \multicolumn{2}{|c|}{$118.10(5)$} & \multicolumn{2}{|l|}{$99.01(5)$} & \multicolumn{2}{|c|}{$147.00(5)$} \\
\hline $\begin{array}{l}\text { Correlation Test- } \\
1\end{array}$ & $\mathrm{c}_{1}$ & \multicolumn{2}{|l|}{-0.81} & \multicolumn{2}{|l|}{-0.85} & -0.94 & & -0.89 & & -0.82 & \\
\hline $\begin{array}{l}\text { Correlation Test- } \\
2\end{array}$ & $\mathrm{c} 2$ & -0.27 & & -0.46 & & -0.44 & & -0.51 & & -0.69 & \\
\hline Hansen & $\mathrm{h}$ & 233.75 & 209) & 259.90 & 208) & 281.22 & 221) & 274.09 & $25)$ & 269.43 & 223) \\
\hline $\mathrm{IP}_{\mathrm{NFOB}},=62 \%$ & & & & & & $=58 \%$ & & & & & \\
\hline
\end{tabular}


These arguments are also in line with previous family literatures as conducted (Barontini and Caprio, 2006). The empirical evidence of model (4) propose that FOBs in which family member serve as $\mathrm{CEO}$ are expected to show better performance than those firms where family member not serve as CEO but the professional CEO instead. The estimated coefficients in do not confirm the hypothesis-4.

In order to check this non-linearity in ownership performance relationship, we compare the coefficients of ownership concentration and its square for family owned companies $(\mathrm{FOB}=1)$ i.e. ( $\beta$ $+\gamma=1.59+1.52=3.11>0)$ and $\left(\beta_{1}+\gamma_{1}=-1.29-1.42=-2.71<0\right)$ are statistical significant. These findings reveal the certain exceeding level of ownership in family firms has negative impact on value as larger stake of family owners create opportunity to expropriate the minority shareholders. We obtain this inflection points (IP) by comparing the estimated coefficients for family as well as non-family companies. The inflection point $62 \%$ and $58 \%$ are estimated for nonfamily and family firms respectively.

\section{CONCLUSIONS AND DISCUSSIONS}

It is concluded that ownership concentration impact stronger in family owned business than non-family ones. In the favor of positive relation between ownership concentration and the value of the firm, the researchers give several arguments theoretically and logically. First, the family owners take more interest due to their motivation level and incentives; try to increase the horizon of business as compared to non-family owners. In the family firms, owners worry more and endeavor to transfer the assets to their decedents than their non-family counterparts. These characteristics of family owned business along with better exposure of background of business are likely induce owners of family firms to set the value maximization criteria for investment. Thus, they always endeavor to maximize their value that further motivates them to refrain from their personal motives and nepotism in appointments. Second, in FOBs owners concern more about reputation and good will of business than the owners in NFOBs which ultimately lead to positive economic consequences for the business. Third, there is less agency problem in FOBs that leads to reduce agency cost because of owners themselves manage and control the activities of business. This relation even seems to be consistent after controlling the general blockholder effect.

Furthermore, the enthusiasm of first generation and involvement of the family members in family owned companies increase the impact and show superior performance in respect to market valuations. We find nonlinear relation between ownership and performance which further reveals family ownership exhibits potential disadvantages in term of value beyond certain level of ownership concentration. We find inverted U-shaped ownership-value relation both in family owned as well as non-family owned businesses. Still family owned companies outperform the nonfamily ones under traditional functional form of business. According to our empirical findings, it is concluded that in Pakistan owners instigates to expropriate at excessive level of ownership 
concentration. In the context of Anglo-Saxon model of ownership structure where corporate decisions are taken on majority voting power of board, widely held companies are questionable.

\section{RECOMMENDATIONS}

1. In light of these empirical results, we able to recommend that family owned business are in excellent position to perform a leading role in Pakistan, especially in the current scenario where terrorism is a big threat for capital markets in our country.

2. As the empirical evidences indicate the better performance of young generation, therefore, it is recommended to regularity authority of Pakistan to take steps for entrepreneur's new businesses in current market.

3. To acquire the rule of value maximization and achieve ultimate goal of business, the family directors must avoid conflicts that might stand up during the transition from one generation to another.

4. It is recommended for family firms to higher professional chief executive offer CEO for the smooth operation of business.

5. The government of Pakistan is recommended to take measure where over concentration of ownership that reduces the value of business.

\section{Funding: This study received no specific financial support.}

Competing Interests: The authors declare that they have no competing interests.

Contributors/Acknowledgement: All authors contributed equally to the conception and design of the study.

\section{REFERENCES}

Aguiló, T.I.E. and N.F.E. Aguiló, 2012. Family business and firm performance: Evidence from the Mexican stock exchange. International Journal of Management Practice, 5(4): 304-325.

Anderson, R.C. and D.M. Reeb, 2003. Founding-family ownership and firm performance: Evidence from the S\&P 500. Journal of Finance, 58(3): 1301-1328.

Attiya, Y. and R. Javaid Iqbal, 2010. Corporate in Pakistan: Corporate valuation, ownership and financing. PIDE Working Paper No. 57.

Barontini, R. and L. Caprio, 2006. The effect of family control on firm value and performance: Evidence from continental Europe. European Financial Management, 12(5): 689-723.

Bebchuk, L.A., A. Cohen and A. Ferrell, 2009. What matters in corporate governance. The Review of Financial Studies, $22(2): 783-827$.

Deloitte, 2013. From the family to the firm: A view through the Indian prism. Available from http://www2.deloitte.com/in/en/pages/human-capital/articles/from-the-family-to-the-firm.html.

Demsetz, H. and K. Lehn, 1985. The structure of corporate ownership: Causes and consequences. Journal of Political Economy, 93(6): 1155-1177. 
Doidge, C., G.A. Karolyi, K.V. Lins and R.M. Stulz, 2005. Private benefits of control, ownership, and the cross-listing decision. Unpublished NBER Working Paper Series No. 11162. The National Bureau of Economic Research. Available from http://www.nber.org/papers.html.

Fitriya, F. and L. Stuart, 2012. Board structure, ownership structure and firm performance: A study of New Zealand listed-firms Asian academy of management. Journal of Accounting and Finance, 8(2): 43-67.

Ghani, W.I. and J. Ashraf, 2005. Corporate governance, business group affiliation and firm performance: Descriptive evidence from Pakistan. Lahore University of Management Sciences. CMER Working Paper No. 05-35.

Gomes, A., 2000. Going public without governance: Managerial reputation affects. Journal of Finance, 55(2): 615-646.

Isik, O. and M. Saykan, 2013. Large shareholders and firm performance: Evidence from Turkey. European Scientific Journal, 9(25): 23-37.

Konijn, S., R. Kräussl and A. Lucas, 2011. Blockholder dispersion and firm value. Journal of Corporate Finance, 17(5): 1330-1339.

La Porta, R., F. Lopez-de-Silanes and A. Shleifer, 1999. Corporate ownership around the world. Journal of Finance, 54(2): $471-517$.

Nazir, M.S., B. Sumaira Asghar and N. Muhammad Musarrat, 2013. Firm performance: Does closely held ownership structure proves to be advantageous in an emerging economy actual problems of economics. АКТУАЛЬНІІ ПРОБЛЕМИ ЕКОНОМІКИ, 9(147).

Nguyen and K. Nielsen, 2013. When blockholders leave feet first: Do ownership and control affect firm value. Unpublished Paper.

Noor Afza, A., 2011. The effect of owner's gender and age to firm performance. Journal of Global Business and Economics January, 2(1): 104-116.

Phung, D.N. and T.P.T. Hoang, 2013. Corporate ownership and firm performance in emerging market: A study of vietnamese listed firms. Proceedings of World Business and Social Science Research Conference 24-25 October, 2013, Novotel Bangkok on Siam Square, Bangkok, Thailand. ISBN: 978-1-922069-33-7.

Salloum, C., E. Bouri and G. Samara, 2013. Impact of family involvement in ownership management and direction on financial performance of the Lebanese firms. International Strategic Management Review, 1(1-2): 30-41.

Shahab-U-Din, A. Javid and M. Imran, 2013. External and internal ownership concentration and debt decisions in an emerging market: Evidence from Pakistan. Asian Economic and Financial Review, 3(12): 1583-1159.

Views and opinions expressed in this article are the views and opinions of the author(s), International Journal of Management and Sustainability shall not be responsible or answerable for any loss, damage or liability etc. caused in relation to/arising out of the use of the content. 